\title{
DRIS FORMULAS FOR EVALUATION OF NUTRITIONAL STATUS OF CUPUAÇU TREES ${ }^{(1)}$
}

\author{
Jairo Rafael Machado Dias ${ }^{(2)}$, Paulo Guilherme Salvador Wadt ${ }^{(3)}$, \\ Daniel Vidal Perez ${ }^{(4)}$, Lucielio Manoel da Silva ${ }^{(5)} \&$ Cleigiane de \\ Oliveira Lemos ${ }^{(6)}$
}

\begin{abstract}
SUMMARY
DRIS, an Diagnosis and Recommendation Integrated System, is a tool to evaluate the nutritional status of plants. Different DRIS formulas have been proposed to improve the efficiency of the crop nutrition diagnoses. The objective of this study was to compare the nutritional diagnosis of the formulas of Beaufils (1973), of Jones (1981) and of Elwali and Gascho (1984), based on the degree of agreement in commercial orchards of Theobrama grandiflorum trees. Leaf samples of 5 to 18 year-old cupuaçu trees were collected from 153 commercial orchards in agroforestry and monoculture systems in the state of Rondonia, Brazil. Bivariate relationships between nutrition concentrations in healthy trees were used to calculate DRIS norms. DRIS indices were calculated based on the different formulas and interpreted by the Potential Fertilizer Response method, in five categories. The DRIS norms, DRIS index calculations and their interpretations were developed using the DRIS Cupuaçu computer program (www.dris.com.br). The different DRIS formulas resulted in similar diagnoses with a degree of agreement of $>90 \%$ for the nutrients $\mathrm{N}, \mathrm{P}, \mathrm{K}, \mathrm{Ca}$, and $\mathrm{Mg}$.
\end{abstract}

Index terms: Theobroma grandiflorum, foliar diagnosis, fruit, nutritional status.

\footnotetext{
(1) Part of the Masters Dissertation of the first author in the Graduate Agronomy Program at the Acre Federal University Received for publication in November 30, 2010 and approved April 5, 2011.

(2) Teacher at Rondonia Federal University. Av. Norte Sul s/n, CEP 76900-000 Rolim de Moura (RO). E-mail: jairorafaelmdias@hotmail.com

(3) Researcher Class A at Embrapa Acre. BR 384, km 14, Caixa Postal 321, CEP 69908-970 Rio Branco (AC). E-mail: paulo@cpafac.embrapa.br

(4) Researcher Class A at Embrapa Acre. Rua Jardim Botânico 1.024, CEP 22460-000 Rio de Janeiro (RJ). E-mail: daniel@cnps.embrapa.br

(5) Analyst Class A at Embrapa Acre. BR 384, km 14, Caixa Postal 321, CEP 69908-970 Rio Branco (AC). E-mail: lucielio@cpafac.embrapa.br

(6) Fellowship DTI/CNPq at Embrapa Acre. BR 384, km 14, Caixa Postal 321, CEP 69908-970, Rio Branco (AC). E.mail: cleigiane@gmail.com
} 


\title{
RESUMO: FÓRMULAS DRIS PARA A AVALIAÇÃO DO ESTADO NUTRICIONAL DE CUPUACYUEIROS
}

\begin{abstract}
O Sistema Integrado de Diagnose e Recomendação (DRIS) é uma ferramenta usada para avaliação do estado nutricional de plantas. Diferentes fórmulas DRIS têm sido propostas para melhorar a eficiência do diagnóstico nutricional de culturas. O objetivo deste trabalho foi comparar o diagnóstico nutricional das fórmulas de Beaufils (1973), de Jones (1981) e de Elwali \& Gascho (1984), por meio do grau de concordância para pomares comerciais de árvores de Theobroma grandiflorum. Amostras foliares de árvores de cupuaçu foram coletadas de 153 pomares comerciais com idade variando entre 5 e 18anos, cultivados em sistemas agroflorestais ou monocultivos, no Estado de Rondônia. Relações bivariadas entre as concentrações dos nutrientes de árvores sadias foram usadas para calcular as normas DRIS. Os índices DRIS foram calculados pelas diferentes fórmulas interpretadas pelo método do Potencial de Resposta à Adubação em cinco categorias. As normas DRIS, o cálculo dos indices DRIS e sua interpretação foram feitos pelo aplicativo computacional Dris Cupuaçu (www.dris.com.br). As diferentes fórmulas DRIS resultaram em diagnósticos similares, com grau de concordância maior que 90 \% para os nutrientes $N, P, K$, Ca e Mg.
\end{abstract}

Termos de indexação: Theobroma grandiflorum, diagnose foliar, frutíferas, estado nutricional.

\section{INTRODUCTION}

Monitoring the nutritional status of fruit trees based on the chemical analysis of the leaves has become an essential practice, underlying a more precisely adapted and financially balanced fertilization (Mourão Filho, 2004). The DRIS evaluation method of the plant nutritional status is considered an effective tool for nutritional diagnosis in Brazil, but less usual than in other countries (Nachtigall \& Dechen, 2007), because it is relatively complicated, compared to traditional methods such as critical level and sufficiency range (Prado, 2008). Nevertheless, it is promising for the nutritional diagnosis of perennial crops, for which calibration tests are generally timeconsuming and costly.

The DRIS method has advantages over traditional methods for being based on nutritional ratios instead of average levels of each nutrient, eliminating dilution and concentration effects that are not dealt with adequately by traditional methods (Wadt, 2009). In addition, variations in the ratios are considered, which allows the development of standardized indices, which are less onerous because they do not require extensive local calibration tests.

The application of this method to fruit trees of different species e.g., apple, mango and citric fruits, has been promising (Nachtigall \& Dechen, 2007; Wadt et al., 2007; Santana et al., 2008). However, for the fruit tree species cupuaçu (Theobroma grandiflorum), widely grown in the Amazon region, there is little information about mineral nutrition and the few studies available address only a limited number of nutrients in fertilizer tests (Alfaia et al., 2004; Ayres \& Alfaia, 2007). The effect of fertilizer application in commercial orchards is therefore to date unknown.

For the DRIS, different methods to calculate functions based on different DRIS formulas have been proposed, with a view to improve the efficiency of the system. The formula developed by Beaufils (1973) has two distinct expressions, depending on the value of the ratio of the leaf sample, compared to the respective DRIS norm. The formula developed by Jones (1981) consists of the standardization of all DRIS functions. The purpose of the formula developed by Elwali \& Gascho (1984) is to nullify nutritional deviation when the values are below the standard deviation from the respective norm.

Several studies evaluated the efficiency of DRIS formulas. Nachtigall \& Dechen (2007) concluded that the formula developed by Elwali \& Gascho (1984) is more efficient than that of Beaufils (1973) or Jones (1981) for apple orchards. On the other hand, Silveira et al. (2005) identified the formula proposed by Jones (1981) as more efficient than that of Beaufils (1973) or Elwali \& Gascho (1984) for signal grass (Brachiaria). These different conclusions are often related to the type of approach to evaluate the efficiency of the different formulas, e.g, the frequency of the most limiting nutrient and correlation between leaf nutrient levels, without necessarily comparing the diagnostic interpretations with each other.

Thus, the objective of this study was to evaluate the performance of the different DRIS formulas in diagnosing the nutritional status of cupuaçu grown in the southeastern Amazon, with a view to identify and recommend the best method for mineral nutrition studies and the monitoring of commercial orchards of the species.

\section{MATERIALS AND METHODS}

Cupuaçu leaves were sampled in commercial orchards from 5 to 18 year old trees grown either in monoculture or agroforestry systems, in Nova 
Califórnia, Porto Velho, in the far West of the state of Rondonia, Brazil. The climate is rainy wet tropical, Am (Köppen), with an annual average of $26^{\circ} \mathrm{C}$ and average rainfall of $2100 \mathrm{~mm}^{-1}$ year $^{-1}$ (Silva, 2000). The predominant soil types are Latosol, Ultosol, Plintosol, and Cambisol.

Sampling was carried out at the end of August and beginning of September 2008, immediately before the beginning of rainy season, in 153 selected orchards. In 111 of these, an agroforesty system was used and a monoculture system in 42. From each orchard, 30 leaves were collected from 10 to 15 randomly distributed plants. Recently matured leaves, the third medium plant were sampled, always facing north south direction, as recommended by Costa (2006).

The leaf samples were chemically analyzed using nitro-perchloric and sulfuric acid digestion. After the digestion, the extracts were analyzed for total contents of $\mathrm{Ca}$ and $\mathrm{Mg}$ by inductively coupled plasma-optical emission spectrometry (ICP-OES), K using flame photometry and $\mathrm{P}$ using molecular spectrophotometry. Total N was obtained by sulfuric digestion and Kjehdahl distillation (Embrapa, 1997).

A database was created to separate the orchards into healthy and unhealthy orchards. At sampling, each orchard was previously classified according to the plant health, taking criteria of plant health and crop and soil management into consideration.

In terms of plant health aspects, the level of infestation by witches' broom (Crinipellis perniciosa) and fruit borer (Conotrachellus humeropictus) was evaluated, which are the diseases that most affect yields in the region (Lopes \& Silva, 1998). For the crop and soil management, the intensity of application of practices considered appropriate were evaluated, i.e.,: pruning, presence of rotten fruit on the ground, and weeding (crop) and organic fertilization, soil cover and planting along contour lines (soil). These properties (plant health state and intensity of crop and soil management practices) were scored: 1 (poor), 2 (satisfactory) and (3) good.

To establish norms, the database was divided into three groups: unhealthy orchards with low (OLY), unhealthy orchards with average (OAY) and healthy orchards with high potential yield (OHY). The criterion for the definition of these classes was given by the sum of these concepts, where: $3 \leq \mathrm{OLY} \leq 5 ; 6 \leq$ $\mathrm{OAY} \leq 7$ and $8 \leq \mathrm{OHY} \leq 9$.

The DRIS norms were calculated for the orchards considered healthy, which comprised 14 monoculture and 34 agroforestry orchards. Although small, the size of the reference population was considered sufficient to generate a representative DRIS norm for healthy orchards (Mourão Filho et al., 2002), which is expected to represent a sample of the nutritional status of the orchards. Even for cereals, a reference population of around 30 fields proved adequate to generate DRIS norms (Guindani et al., 2009).
To generate the DRIS norm, the means, standard deviation and number of observations for each of the ratios between two nutrients were calculated directly and inversely, as well as the levels of each evaluated nutrient in the healthy orchards (OHY), regardless of the cultivation system (Dias et al., 2010).

The DRIS Cupuaçu program (DRIS, 2009) was used to calculate the DRIS indices (IDris), average nutritional balance (NBIa) and IDris interpretations, based on the fertilization response potential. Using software DRIS Cupuaçu (DRIS, 2009), the procedures proposed by Beaufils (1973), Jones (1981) and Elwali \& Gascho (1984) were taken into consideration, including all bivariate relationships (direct and inverse), as follows:

Beaufils (1973):

If $\mathrm{A} / \mathrm{B}<\mathrm{a} / \mathrm{b}$, then:

$$
\mathrm{f}(\mathrm{A} / \mathrm{B})=(\mathrm{A} / \mathrm{B}-\mathrm{a} / \mathrm{b}) / \mathrm{sa} / \mathrm{b} \times(\mathrm{a} / \mathrm{b} / \mathrm{A} / \mathrm{B})
$$

Otherwise:

$$
\mathrm{f}(\mathrm{A} / \mathrm{B})=(\mathrm{A} / \mathrm{B}-\mathrm{a} / \mathrm{b}) / \mathrm{sa} / \mathrm{b}
$$

Jones (1981):

$$
\mathrm{f}(\mathrm{A} / \mathrm{B})=(\mathrm{A} / \mathrm{B}-\mathrm{a} / \mathrm{b}) / \mathrm{sa} / \mathrm{b}
$$

Elwali \& Gascho (1984):

If $\mathrm{A} / \mathrm{B}<\mathrm{a} / \mathrm{b}-\mathrm{sa} / \mathrm{b}$, then:

$$
\mathrm{f}(\mathrm{A} / \mathrm{B})=(\mathrm{A} / \mathrm{B}-\mathrm{a} / \mathrm{b}) / \mathrm{sa} / \mathrm{b} \times(\mathrm{a} / \mathrm{b} / \mathrm{A} / \mathrm{B})
$$

Se $A / B>a / b+s a / b$ :

$$
\mathrm{f}(\mathrm{A} / \mathrm{B})=(\mathrm{A} / \mathrm{B}-\mathrm{a} / \mathrm{b}) / \mathrm{sa} / \mathrm{b}
$$

Otherwise:

$$
\mathrm{f}(\mathrm{A} / \mathrm{B})=0
$$

where $\mathrm{f}(\mathrm{A} / \mathrm{B})$ is the DRIS function for any two nutrients (A and $\mathrm{B}) ; \mathrm{A} / \mathrm{B}$ is the ratio between nutrients $\mathrm{A}$ and $\mathrm{B}$ in the sample; $\mathrm{a} / \mathrm{b}$ is the ratio between nutrients $\mathrm{A}$ and $\mathrm{B}$ in the reference standard; and sa/ $\mathrm{b}$ the standard deviation of ratio $\mathrm{A}$ and $\mathrm{B}$ from the reference standard.

IDris was calculated for each nutrient (Inut) from the arithmetical average of the sum of the differences among all direct and inverse functions that involve the nutrient to be calculated. The NBI was determined by the sum of the modulus of the IDris values generated for the sample, for each nutrient. NBI was calculated using the arithmetical average of the sum of the absolute IDris values generated for each sample. IDris was interpreted by fertilization response potential method (FRP) and classified in five groups (Wadt, 2005): (i) FRP zero (Z) = | Inut $\mid<$ NBIa; (ii) FRP positive or zero $(\mathrm{PZ})=\mid$ Inut $\mid>\mathrm{NBIa}$, with Inut $<0$; (iii) FRP positive $(\mathrm{P})=\mid$ Inut $\mid>\mathrm{NBI}$, where Inut is the lowest DRIS index among the other nutrients; (iv) FRP negative or zero $(\mathrm{NZ})=\mid$ Inut $\mid$ 
$>$ NBIa, where Inut $>0$ and $(v)$ FRP negative $(\mathrm{N})=$ | Inut | > NBIa, where Inut is the highest DRIS index among the other nutrients, where NBIa and Inut are non-dimensional.

To evaluate the three different formulas to calculate DRIS indices, the number of times the nutrients were most limiting because of deficiency, consequently with positive FRP, or most limiting because of excess, with negative FRP, was quantified.

Multivariate statistical parameters (principal component analysis) were used, based on a biplot graph, to evaluate the spatial distribution of the DRIS indices in the different DRIS methods (Lipcovich \& Smith, 2002).

For each nutrient evaluated in each orchard, identified as deficient (FRP positive and FRP positive or zero), in equilibrium (FRP zero) and in excess (FRP negative or FRP negative or zero) according to diagnoses made by each of the DRIS methods, the degree of agreement was evaluated between the different diagnoses. If for a given nutrient the diagnosis (deficiency, equilibrium, or excess) by two different methods was the same in all orchards, it was considered to agree and when different, it was considered to disagree; the degree of agreement between the diagnoses was calculated for all orchards.

The number of cases in which the nutritional diagnosis by the Beaufils (1973) method indicated nutritional equilibrium while Elwali \& Gascho (1984) indicated limitation by deficiency and Jones (1981) limitation by excess was also quantified. Finally, the DRIS methods were correlated to each other based on the DRIS indices of each nutrient and the nutritional balance index (NBI) at $1 \%$ by the $\mathrm{T}$ test, to determine the degree of similarity among the methods resulting from the use of the different DRIS formulas.

Together with the leaves, the soil was sampled under the crown and in the areas between rows in 65 of the orchards. In these samples, pH, exchangeable $\mathrm{Ca}$ and $\mathrm{Mg}$ by $1 \mathrm{~mol} \mathrm{~L}^{-1} \mathrm{KCl}$, potential acidity and available $\mathrm{P}$ and $\mathrm{K}$ by Mehlich-1 were determined, as proposed by Embrapa (1997). Since the analytical results indicated practically the same concentrations and content ranges of the chemical properties under the crown and in the tracks between rows, the averages of the two sampling positions were considered. The soil chemical properties and leaf levels of macroand micro- nutrients were correlated with the DRIS indices obtained by the three methods tested (Pearson at $5 \%)$. Only the most relevant results were presented for discussion.

Test T (Student's correlation) and multivariate (discriminant analysis) were performed using Assistat 7.5 beta and Graphic Biplot 1.0 software, respectively, and the others using electronic spreadsheets. For the Chi-Square test, the expected frequency was assumed to be the mean frequency of cases of deficiency or excess for each nutrient, comparing this frequency with the number of cases observed.

\section{RESULTS AND DISCUSSION}

The soil of the region is highly acidic $(\mathrm{pH} 3.7-5.5$, potential acidity $2.1-9.3 \mathrm{cmol}_{\mathrm{c}} \mathrm{kg}^{-1}$ ), with medium to high $\mathrm{Ca}$ and $\mathrm{Mg}$ levels (1.1-9.7 $\mathrm{cmol}_{\mathrm{c}} \mathrm{kg}^{-1}$ and $0.1-$ $1.6 \mathrm{cmol}_{\mathrm{c}} \mathrm{kg}^{-1}$, respecitvely), $\mathrm{K}$ levels $0.04-$ $0.41 \mathrm{cmol}_{\mathrm{c}} \mathrm{kg}^{-1}$, and available $\mathrm{P} 1-18 \mathrm{mg} \mathrm{kg}^{-1}$ (Table 1). High levels of exchangeable Ca along with high acidity is a common property of many soils of the Formação Solimões (Wadt 2002; Couto 2010), the geological unit from which soils of the region were formed. The P levels are however normally low, and the average of $3 \mathrm{mg} \mathrm{kg}^{-1}$ with a standard deviation of $2 \mathrm{mg} \mathrm{kg}^{-1}$ could be explained by the replenishment with organic fertilizers in many areas of the RECA project.

Independently of the DRIS method for the nutritional diagnoses, in most orchards Ca was most frequently indicated as deficient, i.e., FRP was positive, while $\mathrm{K}$ was most frequently in excess, with negative FRP. The relatively high frequency of orchards with $\mathrm{P}$ and $\mathrm{Mg}$ deficiency was also noted (Table 2).

This result was not supported by the availability of nutrients according to the soil fertility in the study region, indicating that mainly $\mathrm{Ca}$, but also $\mathrm{Mg}$ and $\mathrm{P}$ were more available in the soil than K.

Table 1. Mean values of the chemical properties of the soils of the 65 studied orchards

\begin{tabular}{llcc}
\hline \multicolumn{1}{c}{ Property } & Mean & Standard deviation & Minimum \\
\hline $\mathrm{pH}$ & 4.5 & 0.4 & 5.5 \\
Potential acidity $\left(\mathrm{cmol}_{\mathrm{c}} \mathrm{kg}^{-1}\right)$ & 5.5 & 1.6 & 9.3 \\
Exchangeable Ca $\left(\mathrm{cmol}_{\mathrm{c}} \mathrm{kg}^{-1}\right)$ & 3.1 & 1.7 & 2.1 \\
Exchangeable $\mathrm{Mg}\left(\mathrm{cmol}_{\mathrm{c}} \mathrm{kg}^{-1}\right)$ & 0.7 & 0.4 & 1.1 \\
Available P $\left(\mathrm{mg} \mathrm{kg}^{-1}\right)$ & 3 & 2 & 0.7 \\
Available K $\left(\mathrm{cmol}_{\left.\mathrm{c} \mathrm{kg}^{-1}\right)}\right.$ & 0.16 & 0.07 & 1.6 \\
\hline
\end{tabular}


Table 2. Frequency of cupuaçu orchards with positive response potential (deficiency) and negative (excess) responses to fertilizer ${ }^{(1)}$ diagnosed by DRIS formulas developed by Beaufils (1973), Jones (1981) and Elwali \& Gascho (1984)

\begin{tabular}{|c|c|c|c|c|c|c|c|c|}
\hline \multirow{3}{*}{ Nutrient } & \multicolumn{8}{|c|}{ Frequency $^{\text {ns }}$} \\
\hline & \multicolumn{4}{|c|}{ Deficiency } & \multicolumn{4}{|c|}{ Excess } \\
\hline & Beaufils & Jones & Elwali & FE & Beaufils & Jones & Elwali & FE \\
\hline $\mathrm{N}$ & 22 & 23 & 23 & 23 & 25 & 26 & 28 & 26 \\
\hline $\mathrm{P}$ & 34 & 37 & 33 & 35 & 23 & 22 & 19 & 21 \\
\hline $\mathrm{K}$ & 20 & 20 & 21 & 20 & 52 & 52 & 53 & 52 \\
\hline $\mathrm{Ca}$ & 44 & 44 & 42 & 43 & 30 & 30 & 30 & 30 \\
\hline $\mathrm{Mg}$ & 33 & 29 & 34 & 32 & 23 & 23 & 23 & 23 \\
\hline Orchards & \multicolumn{8}{|c|}{153} \\
\hline
\end{tabular}

(1) Wadt (2005), ns: there was no frequency with different distributions than expected by the chi-square test at $5 \%$.

Although our results are representative for other soils and growing conditions than in the study of Alfaia et al. (2004), it is not clear why Ca was indicated as most often deficient and $\mathrm{K}$ most often in excess.

For $\mathrm{K}$, the high rate of nutrient cycling in agroforestry systems (Côrrea et al., 2006) along with the low levels of transport and relatively high soil fertility in basic cations (Couto, 2010; Table 1) may partially explain the results obtained in the present study.

The Ca nutritional status of cupuaçu trees could be explained by the low internal redistribution rate of the nutrient, which is not mobile among senescing or developing tree organs (Prado, 2008). This leads to a temporary deficiency at the beginning of the period of rapid growth, when there is not enough water in the soil to optimize the mass flow and Ca transport from the roots to the growth points, as suggested to explain the shoot die-back and Ca deficiency indicated by DRIS in young eucalyptus trees (Wadt, 2004). However, more studies are needed to explain this phenomenon, and even to reduce the risk of inconsistent diagnoses, defining the best period for sample leaves when water deficit is not present.

The correlations between $\mathrm{P}, \mathrm{K}, \mathrm{Ca}$ and $\mathrm{Mg}$ levels in the soil and the respective leaf contents or DRIS indices of these nutrients by the formulas developed by Beaufils (1973), Jones (1981) and Elwali \& Gascho (1984) were significant at $5 \%$ for Ca (Table 3). For $\mathrm{P}$, only the soil level and the DRIS indices obtained by the formulas developed by Beaufils (1973) and by Jones (1981) were correlated (Table 3), indicating that at least for $\mathrm{Ca}$ and $\mathrm{P}$, greater availability in the soil results in a better nutritional balance of the respective nutrient, even when the soil and leaf tissue level are not correlated, as in the case of $\mathrm{P}$ (Table 3).

However, the nutritional status of the orchards was similar in the frequency in which each nutrient was indicated as deficient or excessive, independent of the DRIS formula applied (Table 2) for all nutrients by the Chi-Square test at $5 \%$. This result is different from that obtained by Mourão Filho et al. (2002), who found that Jones (1981) formula was more efficient than that of Beaufils (1973) or Elwali \& Gascho (1984) in diagnosing the nutritional status of orange trees.

Multivariate analysis (represented by a biplot of the spatial distribution of the DRIS indices undergoing different DRIS methods, (Lipcovich \& Smith, 2002) indicated that the diagnoses for all nutrients except $\mathrm{P}$ by the formulas developed by Beaufils (1973) and Elwali \& Gascho (1984) were similar (Figure 1). For P, the formulas of Jones (1981) and Elwali \& Gascho (1984) were the most similar (Figure 1). Multivariate analysis indicated that for most DRIS indices, the performance of Jones (1981)' formula was opposite to that of Elwali \& Gascho (1984), which did however not affect the predictive capacity of the nutritional status (Table 2).

Recently, some studies have discussed the efficiency of DRIS functions using the correlation between NBI and yield since the inverse correlation between NBI and yield would define the performance of the methods (Partelli et al., 2006; Silva et al., 2009).

Table 3. Pearson correlation matrix of $\mathbf{P}\left(\mathrm{mg} \mathrm{kg}^{-1}\right)$, $\mathrm{K}, \mathrm{Ca}$ and $\mathrm{Mg}\left(\mathrm{cmol}_{\mathrm{c}} \mathrm{kg}^{-1}\right)$ levels in soil and their respective levels in leaves $\left(\mathrm{g} \mathrm{kg}^{-1}\right)$ or DRIS indices calculated (non-dimensional) using formulas developed by Beaufils (1973), Jones (1981) and Elwali \& Gascho (1984)

\begin{tabular}{cccccc}
\hline \multicolumn{2}{c}{ Element } & & \multicolumn{3}{c}{ DRIS índex } \\
\cline { 1 - 3 } \cline { 5 - 6 } In the soil & In the plant & & Beaufils & Jones & $\begin{array}{c}\text { Elwali \& } \\
\text { Gascho }\end{array}$ \\
\hline $\mathrm{P}$ & 0.241 & & $0.245^{*}$ & $0.247^{*}$ & 0.242 \\
$\mathrm{~K}$ & 0.143 & & 0.159 & 0.125 & 0.179 \\
$\mathrm{Ca}$ & $0.258^{*}$ & & $0.313^{*}$ & $0.283^{*}$ & $0.335^{*}$ \\
$\mathrm{Mg}$ & 0.199 & & 0.182 & 0.184 & 0.231 \\
\hline
\end{tabular}

*: significant at $5 \%$ by the two-tailed Pearson correlation test. 

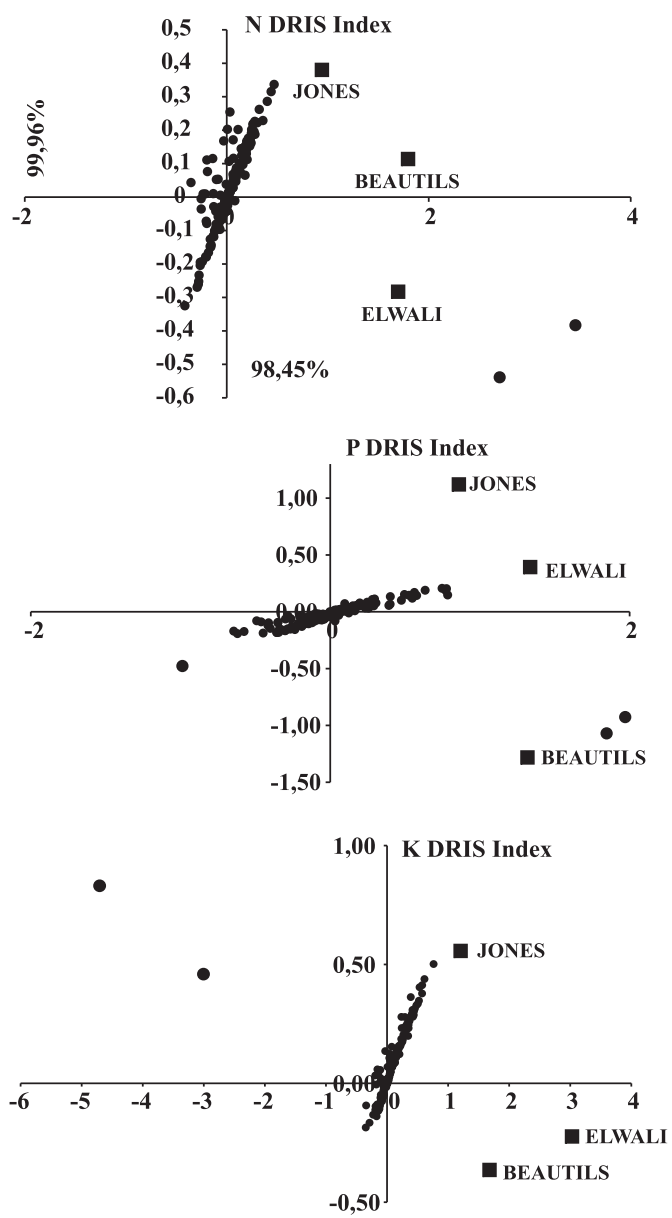
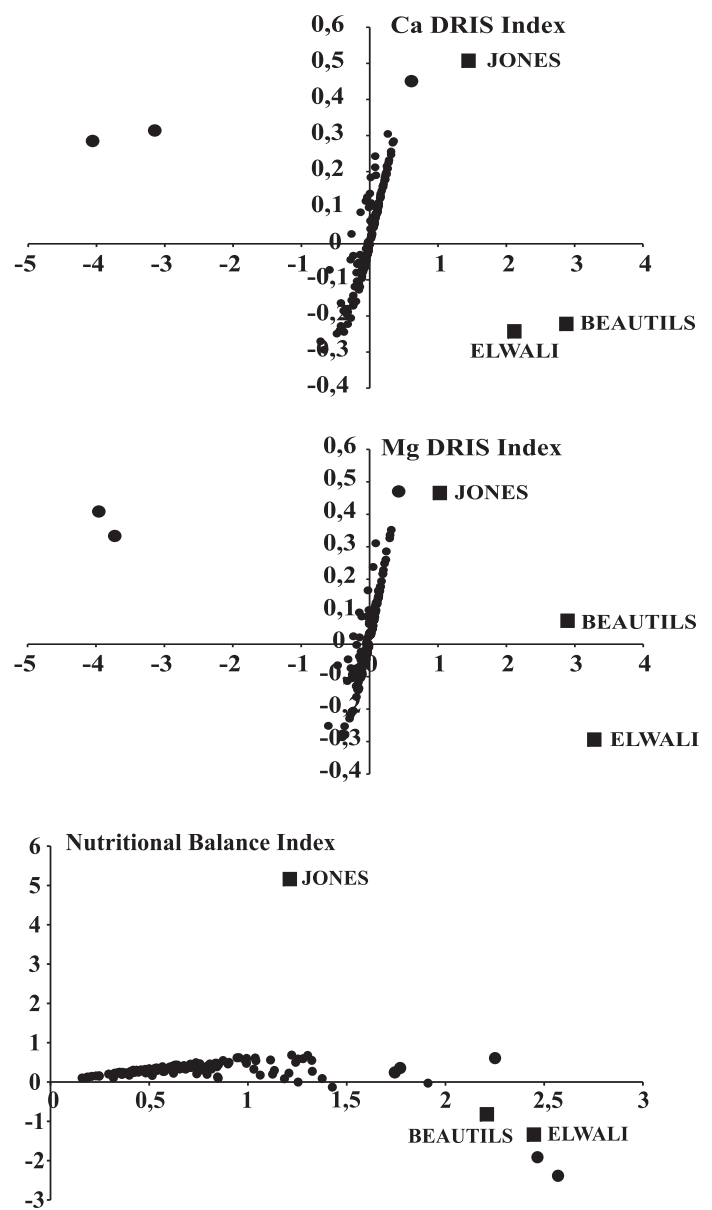

Figure 1. Spatial distribution of N, P, K, Ca and Mg DRIS indices and NBI based on the evaluation of the nutritional status of 153 cupuaçu orchards by different DRIS functions (Beaufils, 1973; Jones, 1981; Elwali \& Gascho (1984), 1984).

Nachtigall \& Dechen (2007) evaluated the efficiency of DRIS methods in apple, concluded that the Elwali \& Gascho (1984) formula was superior to that of Beaufils (1973) and Jones (1981) because the correlation between the nutritional status of apple trees indicated by NBI and yield was better by the former. Based on the correlation between NBI and yield, Silva et al. (2005) reported a contrary result, in that Jones (1981)' formula performed better in evaluating the nutritional status of pastures fertilized with $\mathrm{N}$ and $\mathrm{S}$ compared to the formulas developed by Beaufils (1973) and Elwali \& Gascho (1984).

According to Maia (1999) and Wadt et al. (2007), based solely on evaluation of the mathematical expressions of each formula, the formulas of Beaufils (1973) and Elwali \& Gascho (1984) tend to overestimate nutritional deficiency compared to Jones (1981) formula.

However, when interpreting the nutritional status by the Fertilizer Response Potential (FRP) method (Wadt, 2005) for all nutrients evaluated, there was no significant difference in the distribution at which each nutrient was indicated as deficient or in excess by the different tested DRIS formulas (Figure 2).
Evaluating each diagnosis separately, the Elwali \& Gascho (1984) formula indicated on average $3.4 \%$ more cases of deficiency than Beaufils (1973), while the Jones (1981) formula indicated $1.7 \%$ more cases of excess than Beaufils (1973) (Table 4). That is, six cases of $\mathrm{P}, \mathrm{Ca}$ and $\mathrm{Mg}$, five cases of $\mathrm{N}$ and three cases of K deficiency identified by the Elwali \& Gascho (1984) formula were not identified by that of Beaufils (1973) formula (Table 4). This disagrees with Wadt (1996) and Maia (1999), who evaluated the performance of the DRIS formulas and suggested that the Beaufils (1973) formula tends to diagnose deficiency in more cases than the formulas of Jones (1981) and Elwali \& Gascho (1984).

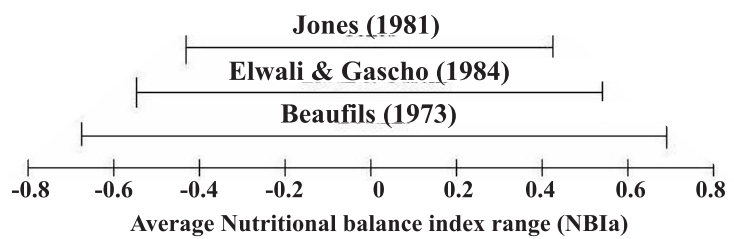

Figure 2. Diagram of the sufficiency interval defined by the NBIa according to the different DRIS formulas. 
By the formula of Elwali \& Gascho (1984), the NBIa value was systematically lower than of Beaufils (1973) since according to Elwali \& Gascho (1984), cases in which the difference between the bivariate ratio in the sample and its norm was below the standard deviation were zeroed, thus diminishing the average NBIa value (Figure 2). With the lower NBIa value, in orchards considered nutritionally balanced by Beaufils (1973)' formula, deficiencies were detected by Elwali \& Gascho (1984) (Table 4).

Jones (1981)' formula led to similar results, with lower NBIa values than the other formulas (Figure 2), which increased the possibility of diagnosing nutritional imbalance (either deficiency or excess), as explained above. However, since the other formulas overestimated deficiencies, Jones (1981)' formula indicated more cases of excess than the other methods, and performed as the Elwali \& Gascho (1984) formula in cases of deficiency.

Based on this performance of the different DRIS formulas and the criterion of Fertilizer Response
Potential, it was decided that Beaufils (1973)' formula should be given preference when it is desirable to diminish false diagnoses of deficiency; Elwali \& Gascho (1984)'s formula should be used to diminish the number of false excess diagnoses (increasing the number of deficiency diagnoses); and Jones (1981)' formula is recommended to diminish the case of false balance diagnoses (increasing the number of cases of deficiency and excess).

Although Beaufils (1973)' formula overestimates deficiencies (Maia, 1999), this effect can be eliminated by the interpretation criterion of the DRIS indices when based on NBIa. It should be emphasized, however, that the differences between the methods are minimal. The correlation of the DRIS indices obtained by the different formulas generally resulted in a correlation coefficient of more than $83 \%$ and all correlations were significant at $1 \%$ by Pearson's correlation analysis. The correlation coefficients between DRIS indices of the nutrients and NBIa obtained by the formulas of Beaufils (1973) and Elwali \& Gascho (1984) were higher than $95 \%$ (Table 5).

Table 4. Number of cases in which the nutritional status is diagnosed as nutritional equilibrium by the Beaufils method (1973) whereas the Elwali \& Gascho (1984) method indicates more limitations by deficiencies and the Jones method (1981) limitations by excess in 153 cupuaçu orchards in the southeastern Amazon

\begin{tabular}{|c|c|c|}
\hline \multirow[b]{2}{*}{ Nutrient } & \multicolumn{2}{|c|}{ Number of cases } \\
\hline & $\begin{array}{l}\text { Sufficient by the formula of Beaufils (1973) } \\
\text { and deficiency by Elwali \& Gascho (1984) }\end{array}$ & $\begin{array}{l}\text { Sufficient by the formula of Beaufils } \\
\text { (1973) and excess by Jones (1984) }\end{array}$ \\
\hline Nitrogen & 5 & 2 \\
\hline Phosphorus & 6 & 2 \\
\hline Potassium & 3 & 5 \\
\hline Calcium & 6 & 3 \\
\hline Magnesium & 6 & 1 \\
\hline Average percentage & $3.40 \%$ & $1.70 \%$ \\
\hline
\end{tabular}

Table 5. Correlation coefficients of the DRIS indices for macronutrients obtained by the DRIS methods developed by Beaufils (1971), Jones (1981) and Elwali \& Gascho (1984), based on the evaluation of the nutritional status of 153 cupuaçu orchards in the southeastern Amazon

\begin{tabular}{|c|c|c|c|}
\hline Correlation & Correlation coefficient & Correlation & Correlation coefficient \\
\hline \multicolumn{2}{|c|}{ Nitrogen } & \multicolumn{2}{|c|}{ Calcium } \\
\hline Beaufils us Jones & $0.84^{* *}$ & Beaufils vs Jones & $0.90 * *$ \\
\hline Beaufils us Elwal & $0.99^{* *}$ & Beaufils vs Elwal & $0.99 * *$ \\
\hline Jones vs Elwali & $0.83^{* *}$ & Jones vs Elwali & $0.90 * *$ \\
\hline \multicolumn{2}{|c|}{ Phosphorus } & \multicolumn{2}{|c|}{ Magnesium } \\
\hline Beaufils vs Jones & $0.87^{* *}$ & Beaufils vs Jones & $0.90 * *$ \\
\hline Beaufils vs Elwal & $0.96^{* *}$ & Beaufils vs Elwal & $0.99 * *$ \\
\hline Jones vs Elwali & $0.95^{* *}$ & Jones vs Elwali & $0.88^{* *}$ \\
\hline \multicolumn{2}{|c|}{ Potassium } & \multicolumn{2}{|c|}{ Nutritional Balance Index } \\
\hline Beaufils vs Jones & $0.86^{* *}$ & Beaufils vs Jones & $0.91^{* *}$ \\
\hline Beaufils vs Elwal & $0.99^{* *}$ & Beaufils vs Elwal & $0.99 * *$ \\
\hline Jones vs Elwali & $0.86^{* *}$ & Jones vs Elwali & $0.90^{* *}$ \\
\hline
\end{tabular}

**: Significant at $1 \%$ by the T Test (Student). 
The high correlation between the indices based on the different DRIS formulas was reflected in the high degree of agreement among diagnoses for all nutrients (Table 6). This high level of agreement among the diagnoses calls for the determination of the consistency between the diagnoses and plant response in relation to the addition or maintenance of nutrient levels, evaluating the diagnoses in fertilizer trials (Wadt \& Lemos, 2010; Wadt \& Silva, 2010).

For example, $\mathrm{Ca}, \mathrm{P}$ and $\mathrm{Mg}$ were, in decreasing order, most frequently identified as limiting in the orchards, while $\mathrm{K}$ was the nutrient with the highest number of excess cases (Table 2). The question arises whether these diagnoses are in fact consistent with the plant response to corrective fertilizer, and if necessary, the DRIS formula should be determined that could improve the level of diagnostic success, for example by diminishing the cases of false diagnoses of balance or imbalance (deficiency or excess).

Table 6. Degree of agreement of nutritional diagnoses among DRIS formulas developed by Beaufils (1973), Jones (1981) and Elwali \& Gascho (1984), in 153 cupuaçu orchards in the southeastern Amazon

\begin{tabular}{lcccc}
\hline Nutrient & $\begin{array}{c}\text { Beaufils } \\
\text { vs } \\
\text { Jones }\end{array}$ & $\begin{array}{c}\text { Beaufils } \\
\boldsymbol{v s} \\
\text { Elwali }\end{array}$ & $\begin{array}{c}\text { Jones } \\
\boldsymbol{v s} \\
\text { Elwali }\end{array}$ & Average \\
\hline Nitrogen & 94.1 & 92.8 & 93.5 & 93.5 \\
Phosphorus & 92.8 & 90.8 & 92.8 & 92.1 \\
Potassium & 93.5 & 96.1 & 96.1 & 95.2 \\
Calcium & 96.1 & 93.5 & 94.1 & 94.6 \\
Magnesium & 94.8 & 90.2 & 90.8 & 91.9 \\
Average & 94.3 & 92.7 & 93.5 & 93.5 \\
\hline
\end{tabular}

\section{CONCLUSIONS}

1. The degree of correlation between the diagnoses based on the formulas proposed by Beaufils (1973), Jones (1981) and Elwali \& Gascho (1984) was high.

2 . The different formulas are equally recommended for analyses of the nutritional status of cupuaçu.

3. Results of the analysis of the nutritional status of cupuaçu based on the different DRIS formulas were not consistent with the interpretation of the availability of $\mathrm{P}, \mathrm{K}, \mathrm{Ca}$ and $\mathrm{Mg}$ in the soils.

\section{ACKNOWLEDGEMENTS}

The authors would like to thank National Council for Scientific and Technological Development (CNPq) and Fundação de Tecnologia do Estado do Acre
(FUNTAC) for financial support of the research project and the producers and technicians of the reforestation project RECA (Reflorestamento Econômico Consorciado Adensado) of Nova Califórnia, Porto Velho, RO for transportation and help with the field work.

\section{LITERATURE CITED}

ALFAIA, S.S.; RIBEIRO, G.A.; NOBRE, A.D.; LUIZÃO, R.C. \& LUIZÃO, J. Evaluation of soil fertility in smallholder agroforestry systems and pastures in Western Amazonia. Agric., Ecosyst. Environ., 102:409-414, 2004.

AYRES, M.I.C. \& ALFAIA, S.S. Calagem e adubação potássica na produção do cupuaçuzeiro em sistemas agroflorestais da Amazônia ocidental. Pesq. Agropec. Bras., 42:957-963, 2007.

BEAUFILS, E.R. Diagnosis and recommendation integrated system (DRIS). Pietermaritzburg, University of Natal, 1973. 132p.

CORREAA, F.L.O.; RAMOS, J.D.; GAMA-RODRIGUES, A.C. MULLER, M.W.; MACEDO, R.G.; SPAGGIARI, C.A. \& ALVARENGA, M.I.R. Ciclagem de nutrientes em sistema agroflorestal com espécies frutíferas e florestais em Rondônia, Brasil. Agrotrópica, 18:71-82, 2006.

COSTA, E.L. Exportação de nutrientes em frutos de cupuaçu (Theobroma grandiflorum) em três solos da Amazônia Central. Manaus, Universidade Federal do Amazonas, 2006. 82p. (Tese de Mestrado)

COUTO, W.H. Indicadores edáficos e potencial agrícola em áreas do Reflorestamento Econômico Consorciado e Adensado (RECA) na Amazônia Ocidental. Seropédica, Universidade Federal Rural do Rio de Janeiro, 2010. 113p. (Tese de Mestrado)

DIAS, J.R.M.; PEREZ, D.V.; SILVA, L.M.; LEMOS, C.O. \& WADT, P.G.S. Normas DRIS para cupuaçuzeiro cultivado em monocultivo e em sistemas agroflorestais. Pesq. Agropec. Bras., 45:64-71, 2010.

DRIS. Sistema Integrado de Diagnose e Recomendação. Disponível em: < http://www.dris.com.br>. Acesso em 10 set. 2009 .

ELWALI, A.M.O. \& GASCHO, G.J. Soil testing, foliar analysis, and DRIS as aguide for sugarcane fertilization. Agron. J., 76:466-70, 1984.

EMPRESA BRASILEIRA DE PESQUISA AGROPECUÁRIA EMBRAPA. Centro Nacional de Pesquisa de Solos. Manual de métodos de análise de solo. 2.ed. Rio de Janeiro, 1997. $212 \mathrm{p}$.

GUINDANI, R.R.H.P.; ANGHINONI, I. \& NACHTIGALL, G.R. DRIS na avaliação do estado nutricional do arroz irrigado por inundação. R. Bras. Ci. Solo, 33:109-118, 2009.

JONES, W.W. Proposed modifications of the diagnosis and recommendation integrated system (DRIS) for interpreting plant analyses. Comm. Soil Sci. Plant Anal., 12:785-794, 1981 
LIPCOVICH, I. \& SMITH, E.P. Biplot and singular value decomposition macros for excel. Virginia, Department Statistics, 2002.

LOPES, C.M.D.A. \& SILVA, N.M. Impacto econômico da broca do cupuaçu, Conotrachelus humeropictus Field (Coleoptera: Curculionidae) nos Estados do Amazonas e Rondônia. Soc. Entomol. Brasil, 27:481-483, 1998.

MAIA, C. Análise crítica da fórmula original de Beaufils no cálculo dos índices DRIS: A constante de sensibilidade. In: WADT, P.G.S. \& MALAVOLTA, E., orgs. Monitoramento nutricional para a recomendação de adubação de culturas. Piracicaba, Potafos, 1999. p.125-145. CD ROM.

MOURAO FILHO, A.A. DRIS: Concepts and applications on nutritional diagnosis in fruit crops. Sci. Agric., 61:550560, 2004.

MOURÃO FILHO, A.A.; AZEVEDO, J.C. \& NICK, J.A. Função e ordens da razão dos nutrientes no estabelecimento de normas DRIS em laranja "Valência". Pesq. Agropec. Bras., 37:185-192, 2002.

NACHTIGALL, G.R. \& DECHEN, A.R. Testing and validation of DRIS for apple tree. Sci. Agric., 64:288-294, 2007.

PARTELLI, F.L.; VIEIRA, H.D.; MONNERAT, P.H. \& VIANA, A.P. Comparison of two DRIS methods for diagnosing nutrients deficiencies in coffee trees. Pesq. Agropec. Bras., 41:301-306, 2006.

PRADO, R.M. Nutrição de plantas. Jaboticabal, Universidade de São Paulo, 2008. 407p.

SANTANA, J.G.; LEANDRO, W.M.; NAVES, R.V. \& CUNHA, P.P. Normas DRIS para interpretação de análise de folhas e solo, em laranjeira pêra, na região central de Goiás. Pesq. Agropec. Trop., 38:109-117, 2008.

SILVA, M.A.C.; NATALE, W.; MALHEIROS, E.B. \& PAVINATO, A. DRIS norms for cotton growth in the center-west region of the Brazil. Acta Sci. Agron., 31:399, 2009.

SILVA, M.J.G. Boletim climatológico de Rondônia, ano 1999. 2.ed. Porto Velho, Secretaria de Estado do Desenvolvimento Ambiental, 2000. 20p.
SILVEIRA, C.P.; NACHTIGALL, G.R. \& MONTEIRO, F.A. Testing and validation of methods for the diagnosis and recommendation integrated system for signal grass. Sci. Agric., 62:520-527, 2005.

WADT, P.G.S. Análise foliar como ferramenta para recomendação de adubação. In: CONGRESSO BRASILEIRO DE CIÊNCIA DO SOLO, 32., Fortaleza, 2009. Anais... Fortaleza, Sociedade Brasileira de Ciência do Solo, 2009. 50p. CD ROM.

WADT, P.G.S. Manejo de solos ácidos do Estado do Acre. Rio Branco, Embrapa Acre, 2002. 28p. (Documento Técnico)

WADT, P.G.S. Nutritional status of Eucalyptus grandis clones evaluated by critical level and DRIS methods. R. Árvore, $28: 15-20,2004$

WADT, P.G.S. Os métodos da chance matemática e do sistema integrado de diagnose e recomendação (DRIS) na avaliação nutricional de plantios de eucalipto. Viçosa, MG, Universidade Federal de Viçosa, 1996. 99p. (Tese de Doutorado)

WADT, P.G.S. Relationships between soil class and nutritional status of coffee crops. R. Bras. Ci. Solo, 29:227-234, 2005.

WADT, P.G.S. \& LEMOS, C.O. Medidas de acurácia para diagnósticos nutricionais e seu impacto no manejo das adubações. In: PRADO, R.M.; CECÍLIO FILHO, A.B.; CORREIA, M.A.R. \& PUGA, A.P., orgs. Nutrição de plantas. Diagnose foliar em hortaliças. Jaboticabal, FCAV/ UNESP, 2010. v.1. p.213-236.

WADT, P.G.S. \& SILVA, D.J. Acurácia do diagnóstico nutricional de pomares de mangueiras obtidos por três fórmulas DRIS. Pesq. Agropec. Bras., v.45, p.1180-1188, 2010 .

WADT, P.G.S.; SILVA, D.J.; MAIA, C.E.; TOME JUNIOR, J.B.; COSTA PINTO, P.A. \& MACHADO, P.L.O.A. Modelagem de funções no cálculo dos índices DRIS. Pesq. Agropec. Bras., 42:57-64, 2007. 
